Article

\title{
Comparison of Fuzzy AHP and AHP in Multicriteria Inventory Classification While Planning Green Infrastructure for Resilient Stream Ecosystems
}

\author{
Yujin Park ${ }^{1}$, Sang-Woo Lee ${ }^{2}$ (i) and Junga Lee ${ }^{3, *}$ \\ 1 Department of Forestry and landscape Architecture, Graduate School, Konkuk University, \\ Seoul 05029, Korea; qkrdbwls333@konkuk.ac.kr \\ 2 Department of Forestry and Landscape Architecture, Konkuk University, Seoul 05029, Korea; \\ sw17311@konkuk.ac.kr \\ 3 Life and Environment Research Institute Sanghuh College of Life Sciences, Konkuk University, \\ Seoul 05029, Korea \\ * Correspondence: archjung@konkuk.ac.kr; Tel.: +82-2-450-3684
}

Received: 6 October 2020; Accepted: 26 October 2020; Published: 30 October 2020

\begin{abstract}
As climate change-induced weather variability increases, various green infrastructure plans, such as stream ecosystems, have been studied to overcome ecological and environmental problems arising from extreme weather events; however, our understanding of them and their resilience to extreme weather events is considerably limited. This study proposes a multicriteria inventory classification while planning green infrastructure for resilient stream ecosystems under extreme weather events. Literature reviews, expert surveys, and reliability/validity analyses were used to enlist indicators for this classification. The analytic hierarchy process (AHP) and fuzzy analytic hierarchy process (fuzzy AHP) were used to compute the weights and ranks of indicators for identifying critical indices while planning green infrastructure. The AHP and fuzzy AHP analysis suggested that meteorological phenomena and disasters, hydraulic characteristic of streams, land use/geographic characteristics, and experience/damage restoration were important factors. High weights were attributed to aquatic ecology, potentially vulnerable areas, population, topography, and heat waves. The weights and ranks attributed by AHP and fuzzy AHP varied slightly, but the indicator groups with high and low weights were the same; hence, primary indicators to be considered while planning green infrastructure for resilient stream ecosystems could be suggested. These results could be used as a preliminary analysis in establishing countermeasures against climate change or in distributing budgets for green infrastructure plans.
\end{abstract}

Keywords: extreme weather events; social-ecological system; analytic hierarchy process; resilience; stream ecosystem

\section{Introduction}

Stream ecosystems are particularly vulnerable to climate change because they are directly affected by extreme weather events caused by climate change and spatiotemporal variability [1]. Extreme weather events, such as drought, flooding, and heat waves lead to fluctuations in water temperature and flow rates in stream ecosystems, resulting in physical, chemical, and biological disturbances in the stream ecosystems [2-4]. Furthermore, extreme weather events affect environmental systems that include stream ecosystems; consequently, the entire environmental system become less resilient [5].

To reduce the damages and disturbances in an environmental system including streams, the concept of resilience needs to be considered. First introduced by Holling [6], in terms of climate change 
and ecology, "resilience" was defined as the ability to absorb disturbances caused by climate change or to self-restructure to continue a prevailing state of transformation into another stable state $[7,8]$. An important way of increasing resilience and reducing the effects of climate change is by developing green infrastructure. Green infrastructure can help in strengthening networks between greenspaces and using natural-based accesses while planning such infrastructure to improve stream ecosystems $[9,10]$. In addition, the structure and function of stream ecosystems could be restored, which would help in improving water quality and storm water storage capacity and reducing the effects of meteorological disasters, ultimately making stream ecosystems more resilient $[11,12]$. The resilience of stream ecosystems is an abstract concept that cannot be directly observed or measured; hence, substitute indicators and variables must be used to determine its attributes $[13,14]$. Stream ecosystems are complex systems affected by social, physical, and biological factors; hence, when determining the indicators for the resilience of stream ecosystems, it is necessary to consider the social-ecological system of a region $[15,16]$.

A social-ecological system is one that encompasses social and natural elements and connects society, economy, and the environment [12]. In green infrastructure, the interaction between social-ecological systems helps identify their vulnerabilities and clarify the indicators that affect them $[17,18]$. Vugteveen et al. [17] used a social-ecological system to derive potential indicators for the integrated management of the Dutch Wadden Sea region, while Flynn and Davidson [12] recognized indicators affecting storm water by using a social-ecological system for storm water management through green infrastructure planning. In addition to determining the indicators that consider the multifunctional aspects of ecology, society, and economy, determining the weights and ranks of each indicator is also important. The weights and ranks could be used as a basis to appropriately allocate budgets when planning green infrastructure and to prepare proactive plans for areas with weak resilience against climate change effects [19]. Kotzee and Reyers [20] used social-ecological system-based indicators whose weights were used to assess flood resilience and provide a basis for disaster policy and planning. Kim et al. [21] assessed the degree of vulnerability of water management to climate change by using vulnerability indicators and their weights, helping identify areas to invest in, for preparing against climate change.

A representative method considering weights and ranks is the analytic hierarchy process (AHP). This method has been widely used in determining evaluation indicators to cope with climate change because it helps relatively represent the influence of indicators, compare each alternative, and examine the suitability of judgment [19,22-25]. However, the AHP has raised challenges in terms of language ambiguity and uncertainty in the decision-making process. The fuzzy AHP, which was introduced to solve this problem, is helping derive weights and priorities of indicators in various fields, such as economics, safety engineering, disaster risk, and water resource management planning [26-28]. In addition, the weights and ranks of various indicators obtained through the AHP and fuzzy AHP were compared to support decision makers in selecting optimal alternatives and indicators [29-32]. The AHP is one of the best ways to make a determination within a complex criteria structure at various levels. The fuzzy AHP is a synthetic extension of the AHP method, given the ambiguity of decision making [33]. Thus, this study presented a comparative analysis of AHP and fuzzy AHP for multicriteria inventory classification. In addition, previous studies have also dealt with vulnerability assessment and the level of resilience in terms of climate change, respectively. Therefore, it has the distinction of being a paper combining green infrastructure planning and vulnerability assessments in order to improve the durability of a stream ecosystem.

Therefore, this study aimed to establish a multicriteria inventory classification for consideration while planning green infrastructure for a resilient stream ecosystem in response to climate change. It also aimed to establish the weights and ranks of various indicators considered in the multicriteria inventory classification and compared the results obtained through the AHP and fuzzy AHP. 


\section{Literature Review}

Streams are a critical aspect of green infrastructure, which not only maintain biodiversity but also provide social and economic benefits [34,35]. However, several climate change induced extreme weather events, including heat waves, droughts, floods, and typhoons, threaten the resilience of stream ecosystems. Previous studies on green infrastructure planning have been conducted to improve the resilience of stream ecosystems in response to climate change. For example, Environmental Protection Agency (EPA) and Yaoze Liu [36,37] presented low-impact development to improve urban water circulation and reduce the effects of floods and storm water, while Han et al. [38] suggested facilities such as rooftop greening and artificial wetlands to control runoff. Beckingham [18] suggested providing ecological services, dampening storm water flows, and reducing pollutants through storm water ponds built using the green infrastructure best management practice method. Chao Mei [39] conducted an integrated assessment based on a storm water management model and life cycle cost analysis to mitigate flooding in urbanized watersheds and identified the most effective green infrastructure strategy. However, studies on green infrastructure planning for stream ecosystems have mainly focused on disaster prevention and hydrologic systems; hence, research concerning water environments and aquatic ecology were found to be relatively scarce [40].

Studies have also been conducted to develop vulnerability assessment indicators to improve resilience to extreme weather events caused by climate change. In the marine sector, indicators were selected to evaluate vulnerability in the fisheries sector [23], resilience in marine regions [41-43], and the effects of climate change on marine organisms [44]. In the agricultural sector, indicators were selected to evaluate the vulnerability to agricultural production infrastructure and productivity $[45,46]$, vulnerability to rice pests [47], and resilience of African agriculture to climate change [48]. In addition, an index was developed based on spatial information to evaluate the vulnerability of forest ecosystems to climate change $[49,50]$, while in the urban sector, the vulnerability to heat waves and urban thermal environments was assessed, and an improvement policy was proposed [24,51,52]. Studies on the effects of climate change on water management have focused on biological elements [53-55], disaster prevention [19,56], and water resources [57-59]. However, research on the effects of climate change on the water quality and aquatic ecosystems of streams is still in a nascent stage $[21,60]$. With climate change induced extreme weather phenomena, resilience indicators for stream ecosystems which suggested for evaluating vulnerability to climate change are related to social system and ecological system directly and indirectly $[21,22,60-66]$. The indicators that help evaluate the frequency and intensity of meteorological disasters, social indicators such as population, and those that play a role in mitigating disasters have been suggested [61-64]. Kim et al. and Kim et al. [21,58] researched the vulnerability of water management and presented indicators for areas directly affected by disasters, and for physical property and human damage caused by disasters. Park et al. and Koh and Kim [22,59] suggested indicators to evaluate the level of stable supply of water resources and access to clean water, and to evaluate economic resources and administrative capabilities when responding to disasters. Han et al. and Myung et al. $[65,66]$ suggested indicators related to social infrastructure that play a pivotal role in maintaining and recovering urban functions during meteorological disasters. Although Ministry of Environment (MOE) and Ryu et al. $[67,68]$ is not a study related to evaluating vulnerability, it is referred to when selecting an indicator because it represents the structure, hydraulic characteristics, and ecological health of streams, and presents social, economic, and environmental indicators that affect streams.

In order to develop a resilient stream ecosystem in response to climate change, previous studies were identified to understand the type of green infrastructure plans required for improving the resilience of stream ecosystems, and to select indicators to evaluate their vulnerability and resilience. Although studies to address climate change have been conducted in various fields, green infrastructure planning and vulnerability assessments have mainly focused on physical factors and disaster prevention. Hence, understanding the ecological, social, and environmental aspects of stream ecosystems was a fundamental step. Therefore, by establishing evaluation indicators through a literature review, 
we aimed to establish a multicriteria inventory classification for consideration while planning green infrastructure for resilient stream ecosystems based on a social-ecological system that helps encompass the complexity of stream ecosystems.

\section{Research Methodology}

\section{1. $A H P$}

This study proposes the use of AHP and fuzzy AHP to determine the weights of indicators in a multicriteria inventory classification. The AHP was devised by Saaty [69] to make the best choice through weights and ranks, considering various alternatives and complex criteria (Table 1). The AHP helps simplify criteria by clarifying the overall goal and organizing complex criteria into a hierarchical structure, such as criteria, sub-criteria, etc. [70]. In addition, the relative weights of the alternatives of each criterion and their overall ranks can be easily identified through a pairwise comparison [71]. The AHP is widely used in various fields requiring decision-making processes and also for weighting of vulnerability assessments of climate change $[23,24,72]$.

Table 1. Comparison scale for AHP [69].

\begin{tabular}{ccc}
\hline Scale & Definition & Explanation \\
\hline 1 & Equal importance & $\begin{array}{c}\text { Two criteria contribute equally to } \\
\text { the objective }\end{array}$ \\
\hline 3 & Moderate importance & $\begin{array}{c}\text { Judgment moderately favors one } \\
\text { criterion over another }\end{array}$ \\
\hline 7 & Strong importance & $\begin{array}{c}\text { Judgment strongly favors one } \\
\text { criterion over another }\end{array}$ \\
\hline 9 & Very strong importance & $\begin{array}{c}\text { One criterion is favored very } \\
\text { strongly over another }\end{array}$ \\
\hline $2,4,6,8$ & $\begin{array}{c}\text { Immediate values between those } \\
\text { of the above scale }\end{array}$ & $\begin{array}{c}\text { There is evidence favoring one } \\
\text { criterion that is of the highest } \\
\text { possible order of affirmation }\end{array}$ \\
\hline Reciprocals & $\begin{array}{c}\text { Compared to activity ' } \mathrm{b} \text { ', if any of the above numbers is assigned to } \\
\text { element ' } \mathrm{a} \text { ', ' } \mathrm{b} \text { ' is the reciprocal of 'a' }\end{array}$ \\
\hline
\end{tabular}

The first step of the AHP involves establishing a hierarchical structure of decision-making problems. A comprehensive goal is established at the top level; thereafter, a connection is made between the top and bottom elements, i.e., the interrelated decision elements to achieve the overall goal. The second step involves a pairwise comparison of the decision elements. To obtain the weight of the decision element, we can ask how much $i$ is preferred for element $j$ compared to each element in the hierarchy consisting of $\mathrm{n}$ elements using a nine-point scale. The nine-point scale is as proposed by Saaty [69] based on Miller's experimental results, wherein the human short-term information processing ability is determined as $7 \pm 2$ and is most often employed when the AHP method is applied [73]. $a_{i j}=1$ means $i$ and $j$ are equally important, $a_{i j}=7$ means $i$ is very strongly more important than $j$, and $a_{i j}=k$ signifies that $a_{j i}=1 / k$. The result of comparing elements $i$ and $j$ can be obtained with the comparison matrix $\mathrm{A}$ $=\left(a_{i j}\right) ; i, j=1,2, \cdots, \mathrm{n}$.

$$
A=\left[\begin{array}{ccc}
1 & \cdots & a_{1 n} \\
\vdots & \ddots & \vdots \\
a_{n 1} & \cdots & 1
\end{array}\right]
$$


The third step involves deleting inconsistent values by verifying consistency. The consistency index $(C I)$ and consistency ratio $(C R)$ are used to verify whether respondents consistently respond to pairwise comparison questions. For example, if the respondents answer that $i$ is more important than $j$, and $j$ is mor important than $k$, then for $i$ and $k$, the respondents should answer that $i$ is more important than $k$. The more consistent the responses, the smaller is the $C I$; and if the $C R$ is $\leq 0.1$, it is determined to be consistent. Criteria with $C R<0.1$ and $<0.2$ are considered reasonable and acceptable, respectively [71]. Here, the $C R$ was set below 0.2 considering that the AHP hierarchical structure consisted of two layers; hence, there are numerous pairwise comparison elements. The $C I$ and $C R$ can be obtained by Equations (2) and (3), where $\lambda_{\max }$ is the principal eigenvalue, and $R I$ is a random index.

$$
\begin{gathered}
C I=\frac{\lambda_{\max }-n}{n-1} \\
C R=\frac{C I}{R I}
\end{gathered}
$$

Finally, the vectors of weights are calculated by Saaty's eigenvector. After comparison matrices are composed, the eigenvector is normalized by Equation (4). Then, the weights are calculated by Equation (5).

$$
\begin{aligned}
a_{i j} & =\frac{a_{i j}}{\sum_{j=1}^{n} a_{i j}} \\
w_{i j} & =\frac{\sum_{j=1}^{n} a_{i j}}{n}
\end{aligned}
$$

\subsection{Fuzzy AHP}

The AHP method has many positive aspects; however, it has a limitation. It is difficult for respondents to clearly determine their preferences as a single value, and the standard of the accepted value could differ depending on the respondent, even if the same value is obtained $[74,75]$. A methodology was required to compensate for the ambiguity and uncertainty of the response due to the linguistic limitations of the AHP, and a fuzzy AHP emerged $[75,76]$. Fuzzy AHP, developed by Laarhoven and Pedrycz [77], is an addition of the existing fuzzy theory to the AHP method to compensate for the disadvantages of AHP. The fuzzy AHP is expressed as an interval using a triangular fuzzy scale rather than a specific value using a nine-point scale to reflect the uncertainty of the selection of respondents [78]. The execution of the fuzzy AHP is outlined here. First, as in the AHP, a hierarchical structure is established and a pairwise comparison is performed; Table 2 shows the scale used for the pairwise comparison [78,79].

Table 2. Triangular scale for the fuzzy number conversion [79].

\begin{tabular}{cccc}
\hline Fuzzy Number & Linguistic Scale & Fuzzy Triangular Scale & Reciprocal Fuzzy Triangular Scale \\
\hline 1 & Equal importance & $(1,1,1)$ & $(1,1,1)$ \\
\hline 3 & Moderate importance & $(1,3 / 2,2)$ & $(1 / 2,2 / 3,1)$ \\
\hline 5 & Strong importance & $(3 / 2,2,5 / 2)$ & $(2 / 5,1 / 2,2 / 3)$ \\
\hline 7 & Very strong importance & $(2,5 / 2,3)$ & $(1 / 3,2 / 5,1 / 2)$ \\
\hline 9 & Extreme importance & $(5 / 2,3,7 / 2)$ & \\
\hline
\end{tabular}

Second, through Equations (6)-(9), the value of the fuzzy synthetic extent $S_{i}=\left(l_{i}, m_{i}, u_{i}\right)$ for the $i^{\text {th }}$ object can be calculated as follows:

$$
S_{i}=\sum_{j=1}^{m} M_{i j} \times\left[\sum_{i=1}^{n} \sum_{j=1}^{m} M_{i j}\right]^{-1}
$$




$$
\begin{gathered}
\text { s.t } \sum_{j=1}^{m} M_{i j}=\left(\sum_{j=1}^{m} l_{i j}, \sum_{j=1}^{m} m_{i j}, \sum_{j=1}^{m} u_{i j}\right) \\
\sum_{i=1}^{n} \sum_{j=1}^{m} M_{i j}=\left(\sum_{i=1}^{m} l_{i j}, \sum_{i=1}^{m} m_{i j}, \sum_{i=1}^{m} u_{i j}\right) \\
{\left[\sum_{i=1}^{n} \sum_{j=1}^{m} M_{i j}\right]^{-1}=\left(\frac{1}{\sum_{i=1}^{n} u_{i j}}, \frac{1}{\sum_{i=1}^{n} m_{i j}}, \frac{1}{\sum_{i=1}^{n} l_{i j}}\right)}
\end{gathered}
$$

Third, the degree of possibility between two fuzzy synthetic extent values is compared. The degree of probability that $S_{j}=\left(l_{j}, m_{j}, u_{j}\right) \geq S_{i}=\left(l_{i}, m_{i}, u_{i}\right)$ is obtained as follows:

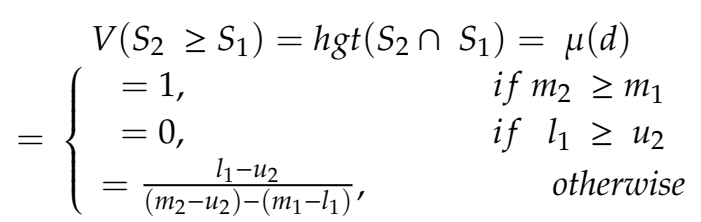

Fourth, the degree of possibility for a convex fuzzy number to be greater than " $k$ " convex fuzzy numbers can be calculated as follows:

$$
=\left\{\begin{array}{c}
V\left(S_{i} \geq S_{1}, S_{2}, \ldots, S_{k}\right) \\
V\left[\left(S_{i} \geq S_{1}\right) \operatorname{and}\left(S_{i} \geq S_{2}\right) \operatorname{and}\left(S_{i} \geq S_{k}\right)\right] \\
\min V\left(S_{i} \geq S_{j}\right), \quad i=1,2,3, \ldots, k
\end{array}\right.
$$

Finally, it is assumed that $d(i)=\min V\left(S_{i}>=S_{k}\right)$. Then, the weight vector is given by $W^{\prime}=\left(d^{\prime}(1), d^{\prime}(2), \ldots, d^{\prime}(i)\right)^{T}$. Through normalization, the normalized weight vectors are $W=(d(1), d(2), \ldots, d(i))^{T}$, where $W$ is a non-fuzzy number.

\subsection{Methodology Framework}

This study aimed to propose a multicriteria inventory classification method on green infrastructure planning for resilient stream ecosystem in response to extreme weather events. In addition, this study examined the relative weights and priorities of classified indicator groups. From previous studies, we extracted 116 potential indicators assessing vulnerability and resilience of stream ecosystems for establishing green infrastructure in response to extreme climate events. To focus on establishing the indicators for a multicriteria inventory classification and calculating their weights for a resilient stream ecosystem, the methodology was systematic/structured. Here, the methodology framework was formulated in three primary stages (Figure 1).

Stage 1: Establishment of the multicriteria inventory classification, which included: (a) gathering potential evaluation indicators from prior studies; (b) classifying the evaluation indicators based on various criteria; and (c) confirming the reliability and validity of the evaluation indicators through a pilot test for the main survey.

A reliability and factor analysis was used for the pilot test, and irrelevant indicators were deleted to refine the classification of the evaluation indicators [80,81]. The respondents consisted of 22 researchers with a master's degree or higher in aquatic ecosystem, resilience, and landscape studies. They were asked questions about the importance of each evaluation indicator, which were scored based on the most used Likert five-point scale. Multiple on-line surveys were performed for the multiple expert groups, including government agencies, engineers, and college educators, during the period of 1 January-31 March in 2020.

Stage 2: Weights and ranks were assigned to the indicators being considered in the multicriteria inventory classification, which included the following: (a) establishing a hierarchical structure and (b) analyzing pairwise comparisons using AHP and fuzzy AHP. 


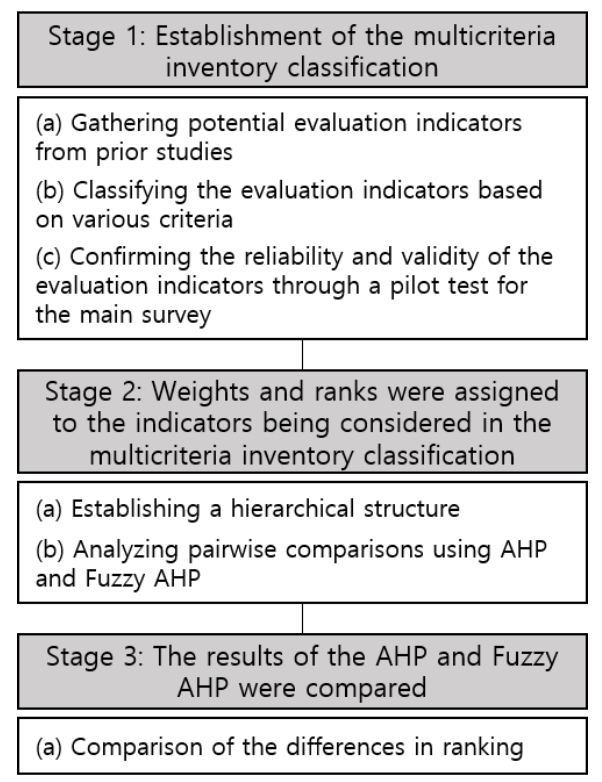

Figure 1. Flow diagram of the methodology framework.

The indicators for a resilient stream ecosystem were confirmed through stage 1 , and the main survey was conducted to obtain their weights and ranks in the multicriteria inventory classification. The main survey was divided into socio-economic and physio-environmental categories, with 110 and 83 respondents, respectively, who each held a master's degree or higher in aquatic ecosystem, resilience, water ecology, and landscape studies. The respondents were selected using the purposive or judgment sampling method to intentionally select a sample suitable for the research subject, and the snowball sampling method was used to expand the number of samples based on the recommendation of the respondents [82].

Stage 3: The results of the AHP and fuzzy AHP were compared; this included a comparison of the differences in ranking.

\section{Results}

\subsection{Establishment of the Multicriteria Classification}

\subsubsection{Gathering Potential Evaluation Indicators from Prior Studies}

Previous studies for gathering evaluation indicators were reviewed using Google Scholar, Web of Science, Scopus and Korea Citation Index (KCI). Keywords included in the literature review were "resilience," "vulnerability," "stream ecosystem," "green infrastructure," and "climate change." Searches were carried out for studies published between 2000 and 2019. In total, 105 research papers and reports were reviewed to enlist indicators for evaluating vulnerability or resilience to climate change, improvement plans considering climate change effects, and for categorizing vulnerable areas. Research that was unrelated to the resilience of stream ecosystems was excluded. Thus, 410 indicators were derived, and 116 potential indicators were selected by excluding indicators having duplicate meanings and those irrelevant to stream ecosystems.

\subsubsection{Classifying Evaluation Indicators Based on "Classification Criteria"}

Based on the social-ecological systems concerning green infrastructure, the indicators for a resilient stream ecosystem were also divided into socio-economic and physio-environmental categories, and the criteria for the classification of these categories were set as shown by Table 3 . 
Table 3. Evaluation indicator classification criteria $[67,83]$.

\begin{tabular}{cccc}
\hline Field & Classification & \multicolumn{2}{c}{ Evaluation Indicator Classification Criteria } \\
\hline & & Population density & Evacuation routes \\
& & Population in flood prone areas & Institutional capacity \\
& Proximity to river/stream & Emergency services \\
& Socio-economic & Past experiences of extreme & Shelters \\
& weather disaster & Land use \\
& Preparedness/awareness & Regional GDP per capita \\
& Quality of water supply & Infrastructure management \\
& Quality of energy supply & Dams and storage capacity \\
& Warming system & Ration of disaster-prone area \\
\cline { 2 - 4 } Stream ecosystem & Groundwater level & Flood duration \\
& & Water quality & River discharge \\
& & Health of aquatic organisms & Flow velocity \\
& Physio-environmental & Rainfall index & Storm surge index \\
& & Recovery time after floods & Drought index \\
& Evaporation rate & Heat wave index \\
& & Dikes/levees & \\
& &
\end{tabular}

The evaluation indicators were organized based on the "evaluation indicator classification criteria," and were classified into physio-environmental and socio-economic categories. Additionally, "evaluation indicator classification criteria" and the evaluation indicators classified accordingly were grouped into division, subdivision, and evaluation indicators to help identify a stream ecosystem and to establish a hierarchical structure for a pairwise comparison. The physio-environmental sector was divided into water quality, topography, biological factors, hydraulic characteristics of streams, meteorological phenomena, and meteorological disasters, while the socio-economic sector was divided into population, land use/geographic characteristics, economy/system, infrastructure, and experience/damage restoration. The results of the multicriteria inventory classification, composed of the indicators classified based on various criteria and a detailed outcome of factor and reliability analyses, are showed in Appendices A and B. Tables 4 and 5 show the summarized results of factor and reliability analyses.

Table 4. Summarized outcome of the factor and reliability analyses considering the physio-environmental sector.

\begin{tabular}{|c|c|c|c|}
\hline Division & Subdivision & Explained Variances & Cronbach's $a$ \\
\hline \multirow{2}{*}{ Water quality } & Water quality assessment & \multirow{2}{*}{79.864} & \multirow{2}{*}{0.831} \\
\hline & Wastewater & & \\
\hline Topography & Topography & 76.893 & 0.696 \\
\hline Biological factors & Aquatic ecology & 87.219 & 0.782 \\
\hline \multirow{3}{*}{ Hydraulic characteristics of stream } & Hydraulic characteristics & \multirow{3}{*}{76.783} & \multirow{3}{*}{0.745} \\
\hline & Runoff & & \\
\hline & groundwater & & \\
\hline \multirow{3}{*}{ Meteorological phenomena } & Heavy rain & \multirow{3}{*}{74.210} & \multirow{3}{*}{0.758} \\
\hline & Typhoons & & \\
\hline & Precipitation & & \\
\hline \multirow{3}{*}{ Meteorological disasters } & Floods & \multirow{3}{*}{74.200} & \multirow{3}{*}{0.725} \\
\hline & Droughts & & \\
\hline & Heat waves & & \\
\hline
\end{tabular}


Table 5. Summarized outcome of the factor and reliability analyses considering the socio-economic sector.

\begin{tabular}{|c|c|c|c|}
\hline Division & Subdivision & Explained Variances & Cronbach's $a$ \\
\hline Population & Population & - & - \\
\hline \multirow{2}{*}{ Land use/Geographic characteristics } & Land use & \multirow{2}{*}{72.217} & \multirow{2}{*}{0.745} \\
\hline & Potentially vulnerable areas & & \\
\hline \multirow{2}{*}{ Economy/System } & Economy & \multirow{2}{*}{75.073} & \multirow{2}{*}{0.745} \\
\hline & Policy capacity & & \\
\hline \multirow{4}{*}{ Infrastructure } & Road/Industry & \multirow{4}{*}{83.692} & \multirow{4}{*}{0.929} \\
\hline & Evacuation & & \\
\hline & Industrial facilities & & \\
\hline & Water supply facilities & & \\
\hline \multirow{3}{*}{ Experience/Damage restoration } & Extent of damage & \multirow{3}{*}{77.885} & \multirow{3}{*}{0.875} \\
\hline & Vulnerable areas & & \\
\hline & Restoration capacity & & \\
\hline
\end{tabular}

\subsubsection{Confirming the Reliability and Validity of Evaluation Indicators}

The pilot test was conducted based on the multicriteria inventory classification to confirm the reliability and validity of the evaluation indicators and to establish their importance. In the pilot test, 21 of the 22 participants responded, and there were 0-3 missing responses for each indicators, depending on its type. The Cronbach's $a$ values for both the physio-environmental and socio-economic sectors indicated that the indicators were reliable (Tables 4 and 5). The number of evaluation indicators was reduced by excluding those having communalities $<0.4$ and low factor loading values through the factor analysis. In addition, indicators with considerably low importance or those that could not be clearly measured were also excluded; thereafter, 85 evaluation indicators were shortlisted.

\subsection{Assigning Weights and Ranks to Indicators Considered in the Multicriteria Inventory Classification}

\subsubsection{Establishing a Hierarchical Structure}

For the main survey, an AHP hierarchical structure was established through the division and subdivision of the evaluation indicators that were reliable and valid. As shown in Figure 2, the top layer of the hierarchical structure highlighted the primary objectives of the study, the first tier had the divisions as judgment criteria, and the second tier had the subdivisions as an alternative. A pairwise comparison of 11 divisions of the judgment criteria hierarchy and 25 subdivisions of the alternative hierarchy was performed based on the AHP hierarchical structure. We received responses from 83 and 110 experts in the physio-environmental and socio-economic sectors, respectively. Respondents with a $C R \geq 0.2$ were excluded from the analysis. Consequently, 74, 56, 60, 59, 98, 87, and 76 respondents for the first tier, hydraulic characteristics, meteorological phenomena, meteorological disasters, land use/geographic characteristics and economy/system, infrastructure, and experience/damage restoration, respectively, were found to have a $C R$ value $\leq 0.2$, and weights were derived using only their responses. 


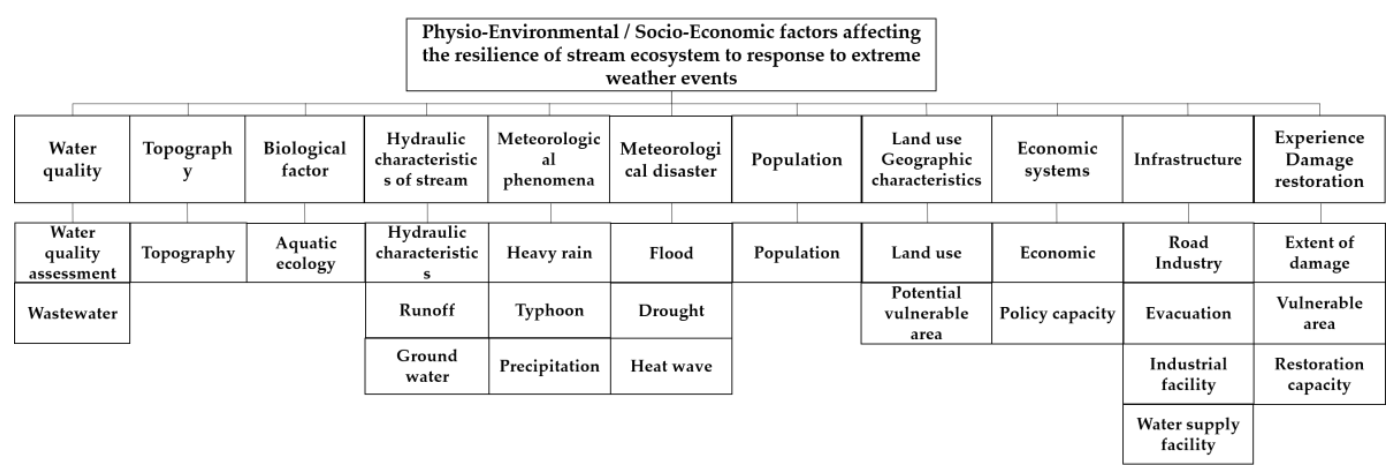

Figure 2. Analytic hierarchy process (AHP) hierarchical structure.

\subsubsection{Analyzing Pairwise Comparison Results through AHP and Fuzzy AHP}

AHP analysis: Table 6 shows the weights and rankings obtained through the AHP. The outcome for the first tier showed that meteorological disasters, land use/geographic characteristics, hydraulic characteristics of streams, and experience/damage restoration could be considered important factors that affect the resilience of a stream ecosystem to cope with extreme weather phenomena, as they ranked high, having weights $>0.1$ points. Additionally, meteorological phenomena, biological factor, and infrastructure were found to have high relative importance, as compared to economy/system, population, and topography.

Table 6. Outcome of the AHP analysis.

\begin{tabular}{|c|c|c|c|c|c|c|c|}
\hline \multicolumn{3}{|c|}{ First Tier } & \multicolumn{3}{|c|}{ Second Tier } & \multicolumn{2}{|c|}{ Overall Outcome } \\
\hline Division & $\begin{array}{c}\text { Local } \\
\text { Weights }\end{array}$ & Rank & Subdivision & $\begin{array}{c}\text { Local } \\
\text { Weights }\end{array}$ & Rank & $\begin{array}{c}\text { Global } \\
\text { Weights }\end{array}$ & Rank \\
\hline \multirow[t]{2}{*}{ Water quality } & \multirow[t]{2}{*}{0.068} & \multirow[t]{2}{*}{9} & $\begin{array}{c}\text { Water quality } \\
\text { assessment }\end{array}$ & 0.54 & 1 & 0.036 & 14 \\
\hline & & & Wastewater & 0.46 & 2 & 0.031 & 16 \\
\hline Topography & 0.063 & 11 & Topography & 1.000 & 1 & 0.063 & 4 \\
\hline Biological factors & 0.089 & 6 & $\begin{array}{l}\text { Aquatic } \\
\text { ecology }\end{array}$ & 1.000 & 1 & 0.089 & 1 \\
\hline \multirow{3}{*}{$\begin{array}{c}\text { Hydraulic } \\
\text { characteristics of } \\
\text { streams }\end{array}$} & \multirow{3}{*}{0.111} & \multirow{3}{*}{3} & $\begin{array}{c}\text { Hydraulic } \\
\text { characteristics }\end{array}$ & 0.371 & 2 & 0.041 & 11 \\
\hline & & & Runoff & 0.403 & 1 & 0.045 & 9 \\
\hline & & & Groundwater & 0.226 & 3 & 0.025 & 20 \\
\hline \multirow{3}{*}{$\begin{array}{l}\text { Meteorological } \\
\text { phenomena }\end{array}$} & \multirow{3}{*}{0.094} & \multirow{3}{*}{5} & Heavy rain & 0.488 & 1 & 0.046 & 8 \\
\hline & & & Typhoons & 0.228 & 3 & 0.022 & 22 \\
\hline & & & Precipitation & 0.284 & 2 & 0.027 & 19 \\
\hline \multirow{3}{*}{$\begin{array}{l}\text { Meteorological } \\
\text { disasters }\end{array}$} & \multirow{3}{*}{0.129} & \multirow{3}{*}{1} & Floods & 0.386 & 2 & 0.05 & 6 \\
\hline & & & Heat waves & 0.429 & 1 & 0.055 & 5 \\
\hline & & & Droughts & 0.185 & 3 & 0.024 & 21 \\
\hline Population & 0.067 & 10 & Population & 1.000 & 1 & 0.067 & 3 \\
\hline
\end{tabular}


Table 6. Cont.

\begin{tabular}{|c|c|c|c|c|c|c|c|}
\hline \multicolumn{3}{|c|}{ First Tier } & \multicolumn{3}{|c|}{ Second Tier } & \multicolumn{2}{|c|}{ Overall Outcome } \\
\hline Division & $\begin{array}{c}\text { Local } \\
\text { Weights }\end{array}$ & Rank & Subdivision & $\begin{array}{c}\text { Local } \\
\text { Weights }\end{array}$ & Rank & $\begin{array}{c}\text { Global } \\
\text { Weights }\end{array}$ & Rank \\
\hline \multirow{2}{*}{$\begin{array}{l}\text { Land } \\
\text { use/geographic } \\
\text { characteristics }\end{array}$} & \multirow{2}{*}{0.116} & \multirow{2}{*}{2} & Land use & 0.407 & 2 & 0.047 & 7 \\
\hline & & & $\begin{array}{l}\text { Potentially } \\
\text { vulnerable } \\
\text { areas }\end{array}$ & 0.593 & 1 & 0.069 & 2 \\
\hline \multirow[b]{2}{*}{ Economy/system } & \multirow[b]{2}{*}{0.0698} & \multirow[b]{2}{*}{8} & Economy & 0.387 & 2 & 0.027 & 18 \\
\hline & & & $\begin{array}{c}\text { Policy } \\
\text { capacity }\end{array}$ & 0.613 & 1 & 0.043 & 10 \\
\hline \multirow{4}{*}{ Infrastructure } & \multirow{4}{*}{0.087} & \multirow{4}{*}{7} & Road/industry & 0.230 & 2 & 0.02 & 23 \\
\hline & & & Evacuation & 0.165 & 4 & 0.014 & 25 \\
\hline & & & $\begin{array}{l}\text { Industrial } \\
\text { facilities }\end{array}$ & 0.228 & 3 & 0.02 & 24 \\
\hline & & & $\begin{array}{l}\text { Water supply } \\
\text { facilities }\end{array}$ & 0.377 & 1 & 0.033 & 15 \\
\hline \multirow{3}{*}{$\begin{array}{l}\text { Experience/damage } \\
\text { restoration }\end{array}$} & \multirow{3}{*}{0.107} & \multirow{3}{*}{4} & $\begin{array}{l}\text { Extent of } \\
\text { damage }\end{array}$ & 0.263 & 3 & 0.028 & 17 \\
\hline & & & $\begin{array}{c}\text { Vulnerable } \\
\text { areas }\end{array}$ & 0.353 & 2 & 0.038 & 13 \\
\hline & & & $\begin{array}{l}\text { Restoration } \\
\text { capacity }\end{array}$ & 0.384 & 1 & 0.041 & 12 \\
\hline
\end{tabular}

Considering the global weights, aquatic ecology demonstrated the highest importance, followed by potentially vulnerable areas, population, topography, heat waves, and floods, which demonstrated high importance in that order; land use, heavy rain, and runoff demonstrated an upper-middle rank. Policy capacity, hydraulic characteristics, and restoration capacity were ranked together, while vulnerable areas, water quality assessment, water supply facilities, and wastewater were ranked in the middle. Extent of damage, precipitation, economy, and groundwater demonstrated a similar low importance, followed by road/industry and industrial facilities; evacuation demonstrated the lowest importance.

Fuzzy AHP analysis: Table 7 shows the weights and ranking of indicators obtained through the fuzzy AHP. Meteorological disasters, hydraulic characteristics of streams, and land use/geographic characteristics ranked the highest in the first tier and were considered important factors affecting the goal of the hierarchical structure. Meteorological phenomena, experience/damage restoration, biological factors, and infrastructure ranked in the middle; however, water quality, population, topography, and economy/system had low weights.

Considering global weights, aquatic ecology was the most important, followed by population, topography, and potentially vulnerable areas. Heat waves, water quality assessment, runoff, policy capacity, land use, and hydraulic characteristics demonstrated an upper-middle rank, while floods, heavy rain, wastewater, restoration capacity, water supply facilities, and vulnerable areas ranked in the middle. Economy, typhoons, precipitation, road/industry, extent of damage, droughts, groundwater, and evacuation ranked lower, while industrial infrastructure had the lowest weight. 
Table 7. Outcome of the fuzzy AHP analysis.

\begin{tabular}{|c|c|c|c|c|c|c|c|}
\hline \multicolumn{3}{|c|}{ First Tier } & \multicolumn{3}{|c|}{ Second Tier } & \multicolumn{2}{|c|}{ Overall Outcome } \\
\hline Division & $\begin{array}{c}\text { Local } \\
\text { Weights }\end{array}$ & Rank & Subdivision & $\begin{array}{c}\text { Local } \\
\text { Weights }\end{array}$ & Rank & $\begin{array}{c}\text { Global } \\
\text { weights }\end{array}$ & Rank \\
\hline \multirow[t]{2}{*}{ Water quality } & \multirow[t]{2}{*}{0.081} & \multirow[t]{2}{*}{8} & $\begin{array}{l}\text { Water quality } \\
\text { assessment }\end{array}$ & 0.055 & 1 & 0.045 & 6 \\
\hline & & & Wastewater & 0.045 & 2 & 0.037 & 13 \\
\hline Topography & 0.076 & 10 & Topography & 1.000 & 1 & 0.076 & 3 \\
\hline Biological factors & 0.094 & 6 & Aquatic ecology & 1.000 & 1 & 0.094 & 1 \\
\hline \multirow{3}{*}{$\begin{array}{c}\text { Hydraulic } \\
\text { characteristics of } \\
\text { streams }\end{array}$} & \multirow{3}{*}{0.107} & \multirow{3}{*}{2} & $\begin{array}{c}\text { Hydraulic } \\
\text { characteristics }\end{array}$ & 0.398 & 2 & 0.042 & 10 \\
\hline & & & Runoff & 0.411 & 1 & 0.044 & 7 \\
\hline & & & Groundwater & 0.196 & 3 & 0.021 & 23 \\
\hline \multirow{3}{*}{$\begin{array}{l}\text { Meteorological } \\
\text { phenomena }\end{array}$} & \multirow{3}{*}{0.097} & \multirow{3}{*}{4} & Heavy rains & 0.396 & 1 & 0.039 & 12 \\
\hline & & & Typhoons & 0.304 & 2 & 0.03 & 18 \\
\hline & & & Precipitation & 0.301 & 3 & 0.029 & 19 \\
\hline \multirow{3}{*}{$\begin{array}{l}\text { Meteorological } \\
\text { disasters }\end{array}$} & \multirow{3}{*}{0.109} & \multirow{3}{*}{1} & Floods & 0.354 & 2 & 0.039 & 11 \\
\hline & & & Heat waves & 0.440 & 1 & 0.048 & 5 \\
\hline & & & Droughts & 0.206 & 3 & 0.022 & 22 \\
\hline Population & 0.078 & 9 & Population & 1.000 & 1 & 0.078 & 2 \\
\hline \multirow{2}{*}{$\begin{array}{c}\text { Land } \\
\text { use/geographic } \\
\text { characteristics }\end{array}$} & \multirow{2}{*}{0.101} & \multirow{2}{*}{3} & Land use & 0.421 & 2 & 0.042 & 9 \\
\hline & & & $\begin{array}{c}\text { Potentially } \\
\text { vulnerable areas }\end{array}$ & 0.579 & 1 & 0.058 & 4 \\
\hline \multirow{2}{*}{ Economy/system } & \multirow{2}{*}{0.074} & \multirow{2}{*}{11} & Economy & 0.404 & 2 & 0.03 & 17 \\
\hline & & & Policy capacity & 0.596 & 1 & 0.044 & 8 \\
\hline \multirow{4}{*}{ Infrastructure } & \multirow{4}{*}{0.088} & \multirow{4}{*}{7} & Road/industry & 0.314 & 2 & 0.028 & 20 \\
\hline & & & Evacuation & 0.216 & 3 & 0.019 & 24 \\
\hline & & & $\begin{array}{l}\text { Industrial } \\
\text { facilities }\end{array}$ & 0.069 & 4 & 0.006 & 25 \\
\hline & & & $\begin{array}{l}\text { Water supply } \\
\text { facilities }\end{array}$ & 0.400 & 1 & 0.035 & 15 \\
\hline \multirow{3}{*}{$\begin{array}{l}\text { Experience/damage } \\
\text { restoration }\end{array}$} & \multirow{3}{*}{0.095} & \multirow{3}{*}{5} & Extent of damage & 0.266 & 3 & 0.025 & 21 \\
\hline & & & Vulnerable areas & 0.375 & 2 & 0.036 & 14 \\
\hline & & & $\begin{array}{l}\text { Restoration } \\
\text { capacity }\end{array}$ & 0.359 & 1 & 0.034 & 16 \\
\hline
\end{tabular}

\subsection{Comparison between the AHP and Fuzzy AHP Results}

The AHP and fuzzy AHP methods were used to analyze the relative importance of the indicators in the proposed multicriteria inventory classification to make stream ecosystems more resilient. On comparing the outcomes of the two weighting analysis methods for the first tier, the ranks were not significantly different, except for those of the meteorological disasters, biological factors, and infrastructure. The ranks of hydraulic characteristics of streams, land use/geographic characteristics, meteorological phenomena, and experience/damage restoration changed using the fuzzy AHP. Economy/system had the lowest weight; consequently, the ranking of water quality, population, and topography rose by one step. Considering the weights, those of the top ranking indicators using the AHP (meteorological disasters, land use/geographic characteristics, hydraulic characteristics of streams and experience/damage restoration), were slightly lower than in the fuzzy AHP, whereas those of the other divisions were higher. The ranks of indicators in the second tier using the AHP and fuzzy AHP were the same, except for those of meteorological phenomena and infrastructure. Using the fuzzy AHP, typhoons under meteorological phenomena ranked higher than precipitation, while evacuation 
under infrastructure ranked higher than industrial facilities. Overall, all the rankings were different, except for those of aquatic ecology, heat waves, water supply facilities, and precipitation.

Using the AHP and fuzzy AHP, the weights and ranks of indicators slightly varied, but the indicator groups with high and low weights remained the same. In the first tier, the groups that demonstrated high weights included meteorological disasters, land use/geographic characteristics, hydraulic characteristics of streams, experience/damage restoration, meteorological phenomena, biological factors, and infrastructure, while the groups that demonstrated low weights included water quality and population, followed by topography. In addition, in the overall result, the groups demonstrating high weights included aquatic ecology, potentially vulnerable areas, population, topography, and heat waves, while the group demonstrating low weights included typhoons, precipitation, road/industry, extent of damage, droughts, groundwater, evacuation, and industrial facilities.

\section{Discussion}

To improve the resilience of stream ecosystems, a multicriteria inventory classification was proposed considering green infrastructure, and weights and ranks of indicators were derived using the AHP and fuzzy AHP. The differences in the outcomes through the AHP and fuzzy AHP could have arisen because of the variations in the analysis of the decisions of respondents. The AHP expressed the opinions of respondents as single numbers, which significantly affected the overall result, whereas fuzzy AHP displayed the opinions of respondents as triangular fuzzy numbers, taking into account the ambiguity of languages and uncertainties arising through human judgment $[28,31,78]$. Although the ranks and weights of indicators using the AHP and fuzzy AHP varied due to the above reasons, the high-weighted and low-weighted indicator groups remained the same for the first tier and the final overall result. Considering the same group, it is possible to know the indicators that could be first considered when planning green infrastructure to enhance the resilience of stream ecosystems in response to climate change.

Meteorological disasters, hydraulic characteristics of streams, land use/geographic characteristics, meteorological phenomena, and experience/damage restoration showed high weights in both the AHP and fuzzy AHP results for the first tier. In particular, meteorological disasters ranked first in both the methods. Meteorological disasters appear to have been attributed higher weights than other evaluation indicators in previous studies that developed climate change vulnerability assessments; they are indicators that expose social-ecological systems to disturbances, suggesting that they greatly influence the resilience of stream ecosystems $[2,19,21,65,84]$. The high ranking of land use/geographic characteristics could be attributed to the fact that land use affects stream ecologies and water quality [15], while the geographic characteristics of potentially vulnerable areas directly affects the scale of damage due to disasters [85]; moreover, high weights were attributed to these factors in previous studies [22,84]. Extreme meteorological phenomena cause fluctuations in the hydraulic characteristics of streams [86], in turn causing secondary damage, such as affecting the ecological function of streams [87]. A high weight seems to have been attributed to the hydraulic characteristics of streams because of the effect of basin management and maintenance plans of streams [88]. Considering the division for experience/damage restoration, it was found that the factors related to restoration could be considered important because the weight of the relevant division was high, as an indicator added in regard to resilience, unlike in previous studies. Other divisions (infrastructure, water quality, population, and economy/system) that were relatively low-weighted were indirectly influenced by the high-weighted ones; prior studies demonstrated that the evaluation indicators belonging to these divisions were attributed low weights $[19,21,84,89]$.

Considering global weights, aquatic ecology, potentially vulnerable areas, population, and topography ranked high; aquatic ecology ranked the highest in both the AHP and fuzzy AHP results. The aquatic ecology subdivision includes the evaluation indicators of aquatic health index and lateral/vertical continuity of streams. The aquatic health index has been investigated and evaluated by the Ministry of Environment, considering the trophic diatom index (TDI), benthic macroinvertebrates 
(BMI), fish assessment index (FAI), habitat and riparian index (HRI), radar vegetation index (RVI), and water quality in streams across Korea for over 10 years. These aquatic health indices continue to be important as they help identify the changing trends in aquatic ecosystems [68]. The lateral/vertical continuity of streams contributes to the movement of energy and materials in a linear stream ecosystem; it is an important factor for the long-term survival of fish and other aquatic life by connecting various habitats [90]. Therefore, it is considered that the aquatic health index and lateral/vertical continuity of a stream indicates the biological and structural characteristics of the stream ecosystem, respectively, which are considered to have high weights.

Population and topography showed the lowest ranking in the first tier; however, they ranked high as global weights. This is because the global weight was calculated with the weight of the second tier set to one, as there was no comparable subdivision for either population or topography in the pairwise comparison of the second tier due to the limitation of the hierarchical structure for the pairwise comparisons. Therefore, in future studies, when planning green infrastructure for resilient stream ecosystems by selecting an actual study site, it is necessary to verify the effects of the weight of the selected evaluation indicators on the overall results and to continue supplementing the weights with the actual applied results.

\section{Conclusions}

In this study, a multicriteria inventory classification was established to help plan green infrastructure for resilient stream ecosystems to cope with extreme weather phenomena caused by climate change. First, based on the evaluation indicator classification criteria, the evaluation indicators of previous studies that helped conduct assessments of vulnerability toward climate change and the indices that affect stream ecosystems were classified. The classified evaluation indicators were confirmed through reliability and validity tests. Finally, the multicriteria inventory classification was presented considering the physio-environmental and socio-economic sectors. In addition, based on this suggested classification, a survey was conducted with experts to derive the weights and ranks of the various indicators. By analyzing the weights and ranks of the indicators considered in the multicriteria inventory classification, the indicators that could be first considered when planning green infrastructure of a stream ecosystem were grouped.

The comparison between the weights and ranks of the indicators derived using the AHP and fuzzy AHP showed slight variations in their weights and rankings in the first tier. Meteorological disasters, land use/geographic characteristics, hydraulic characteristics of streams, experience/damage restoration, meteorological phenomena, biological factors, and infrastructure received high weights, while water quality, population, economy/system, and topography received relatively low weights. There was also a difference in the indicator weights in the second tier, but their ranks were the same except for those of typhoons and precipitation under the weather phenomena and for evacuation and industrial facilities under infrastructure. In the final overall result, aquatic ecology, population, topography, potentially vulnerable areas, and heat waves received high weights, while typhoons, precipitation, road/industry, extent of damage, droughts, groundwater, evacuation, and industrial facilities received low weights. Although the weights and ranks of indicators varied using the AHP and fuzzy AHP, indicator groups with high and low weights were the same; it was also possible to identify indicators of the social-ecological system that could be mainly considered when planning green infrastructure for resilient stream ecosystems.

By helping derive weights and ranks of indicators, the study could be valuable in suggesting data that could be referred to when establishing countermeasures and distributing budgets for ensuring the resilience of stream ecosystems against climate change. Moreover, unlike existing studies which deal with vulnerability assessments and resilience in the face of extreme weather phenomena, this study benefits from the distinction of combining vulnerability assessment and green infrastructure planning so as to improve the resilience of stream ecosystems. However, a limitation exists in determining the weights and ranks of indicators in the presented multicriteria inventory classification. This is because 
the weights of indicators in the first tier were used as they were for the indicators having only one subdivision in the second tier, when global weights were assigned; consequently, in the final overall result, the subdivisions that ranked lower then ranked high. Therefore, it is necessary to help clarify the weights and ranks of indicators considered in this classification through additional research on weights. In future research, based on the multicriteria inventory classification suggested here, it is necessary to evaluate the resilience of an actual stream ecosystem and to select regions with weak resilience to help analyze spatiotemporal changes in a stream ecosystem due to extreme weather phenomena. In addition, if the selected vulnerable area is categorized and a response strategy for each category is established through a relationship analysis between the factors of the multicriteria inventory classification, and if a practical method to improve resilience is established by comprehensively analyzing the response strategies for each basin, scale unit, and meteorological phenomena, the resilience of stream ecosystems could be further improved.

Author Contributions: Study design conceptualization, Y.P. and J.L.; writing—original draft preparation, Y.P.; writing-review and editing, S.L. and J.L. All authors have read and agreed to the published version of the manuscript.

Funding: This work was supported by the National Research Foundation of Korea (NRF) grant funded by the Korea government (MSIT) (No.2019R1F1A1063823; 2018R1D1A1B07050805). This paper was also supported by the KU Research Professor Program of Konkuk University.

Conflicts of Interest: The authors declare no conflict of interest. 


\section{Appendix A}

Table A1. Multicriteria inventory classification of evaluation indicators considering the physio-environmental sector and the outcome of the factor and reliability analyses.

\begin{tabular}{|c|c|c|c|c|c|c|c|}
\hline Division & Subdivision & Evaluation Indicator & Factor Loading & Communalities & Explained Variances & Cronbach's $\alpha$ & Prior Studie: \\
\hline \multirow{11}{*}{ Water quality } & \multirow{8}{*}{$\begin{array}{l}\text { Water quality } \\
\text { assessment }\end{array}$} & Hydrogen ion concentration $(\mathrm{pH})$ & 0.761 & 0.841 & \multirow{11}{*}{79.861} & \multirow{11}{*}{0.831} & {$[68,91]$} \\
\hline & & Biological oxygen demand (BOD) & 0.738 & 0.923 & & & {$[67,68,92]$} \\
\hline & & Chemical oxygen demand (COD) & 0.620 & 0.857 & & & {$[67,68,92]$} \\
\hline & & Total organic carbon (TOC) & 0.840 & 0.894 & & & {$[68]$} \\
\hline & & Suspended solids (SS) & 0.867 & 0.776 & & & [68] \\
\hline & & $\begin{array}{l}\text { Dissolved oxygen concentration } \\
\text { (DO) }\end{array}$ & 0.656 & 0.808 & & & [68] \\
\hline & & Total phosphorus (T-P) & 0.657 & 0.841 & & & {$[67,68,89,92]$} \\
\hline & & $\begin{array}{l}\text { Count of coliform group } \\
\left(\mathrm{MPN}^{1} / 100 \mathrm{~mL}\right)\end{array}$ & 0.652 & 0.503 & & & [68] \\
\hline & \multirow{3}{*}{ Waste water } & $\begin{array}{l}\text { Whether certain water pollutants } \\
\text { are released }\end{array}$ & & 0.750 & & & [64] \\
\hline & & $\begin{array}{l}\text { Water pollution prevention } \\
\text { facility capacity }\end{array}$ & 0.952 & 0.933 & & & [65] \\
\hline & & $\begin{array}{l}\text { Nonpoint pollution reduction } \\
\text { facility capacity }\end{array}$ & 0.575 & 0.659 & & & {$[64,92]$} \\
\hline \multirow{2}{*}{ Topography } & \multirow{2}{*}{ Topography } & Riverside width & 0.877 & 0.769 & \multirow{2}{*}{76.893} & \multirow{2}{*}{0.696} & {$[68]$} \\
\hline & & Transverse structures & 0.877 & 0.769 & & & [68] \\
\hline \multirow{2}{*}{ Biological factors } & \multirow{2}{*}{ Aquatic ecology } & Aquatic health index & 0.934 & 0.872 & \multirow{2}{*}{87.219} & \multirow{2}{*}{0.782} & {$[67,68]$} \\
\hline & & Stream lateral/vertical continuity & 0.934 & 0.872 & & & {$[67,68]$} \\
\hline \multirow{6}{*}{$\begin{array}{c}\text { Hydraulic } \\
\text { characteristics of } \\
\text { streams }\end{array}$} & \multirow{4}{*}{$\begin{array}{c}\text { Hydraulic } \\
\text { characteristics }\end{array}$} & $\begin{array}{l}\text { Stream density of small } \\
\text { watersheds }\end{array}$ & 0.894 & 0.808 & \multirow{6}{*}{76.783} & \multirow{6}{*}{0.745} & [93] \\
\hline & & Average river temperature & 0.611 & 0.561 & & & [91] \\
\hline & & Flow rate & 0.876 & 0.914 & & & [92] \\
\hline & & Flux & 0.879 & 0.785 & & & [92] \\
\hline & \multirow{2}{*}{ Runoff } & $\begin{array}{l}\text { Hundred-year frequency of daily } \\
\text { direct runoff }\end{array}$ & 0.718 & 0.789 & & & [84] \\
\hline & & Daily maximum runoff & 0.628 & 0.600 & & & {$[61,94]$} \\
\hline
\end{tabular}


Table A1. Cont.

\begin{tabular}{|c|c|c|c|c|c|c|c|}
\hline Division & Subdivision & Evaluation Indicator & Factor Loading & Communalities & Explained Variances & Cronbach's $\alpha$ & Prior Studies \\
\hline \multirow{10}{*}{$\begin{array}{l}\text { Meteorological } \\
\text { phenomena }\end{array}$} & & Annual maximum runoff & 0.928 & 0.884 & \multirow{10}{*}{74.210} & \multirow{10}{*}{0.758} & {$[58,62,95]$} \\
\hline & Groundwater & Groundwater level & 0.869 & 0.801 & & & {$[59,83,96]$} \\
\hline & Heavy rain & $\begin{array}{l}\text { "Heavy rain” warning level } \\
\text { rainfall }\end{array}$ & 0.742 & 0.563 & & & {$[66,94]$} \\
\hline & Typhoons & Frequency of typhoon occurrence & 0.857 & 0.826 & & & [66] \\
\hline & \multirow{6}{*}{ Precipitation } & Annual precipitation & 0.883 & 0.790 & & & {$[45,62,93,95-97]$} \\
\hline & & $\begin{array}{l}\text { Average daily precipitation over } \\
\qquad 80 \mathrm{~mm}\end{array}$ & 0.821 & 0.834 & & & {$[13,45,95]$} \\
\hline & & $\begin{array}{l}\text { Hundred-year frequency of } \\
\text { precipitation }\end{array}$ & 0.680 & 0.832 & & & {$[84,94]$} \\
\hline & & Maximum precipitation per day & 0.561 & 0.524 & & & $\begin{array}{l}{[2,13,21,45,61,62} \\
64,65,95,98-100]\end{array}$ \\
\hline & & $\begin{array}{l}\text { Average number of consecutive } \\
\text { days without precipitation }\end{array}$ & 0.878 & 0.785 & & & [64] \\
\hline & & Evaporation rate & 0.862 & 0.783 & & & [96] \\
\hline \multirow{7}{*}{$\begin{array}{l}\text { Meteorological } \\
\text { disasters }\end{array}$} & Floods & Hundred-year flood volume & 0.767 & 0.589 & \multirow{7}{*}{74.200} & \multirow{7}{*}{0.725} & [66] \\
\hline & \multirow{2}{*}{ Droughts } & $\begin{array}{l}\text { Number of days under } \mathrm{SPI}^{2}-1 \text { for } \\
\text { three months a year }\end{array}$ & 0.954 & 0.711 & & & [92] \\
\hline & & $\begin{array}{l}\text { Number of days under } \mathrm{EDI}^{3}-1 \text { for } \\
\text { three months a year }\end{array}$ & 0.927 & 0.413 & & & [92] \\
\hline & \multirow{4}{*}{ Heat waves } & $\begin{array}{l}\text { Number of days over the highest } \\
\text { heat index of } 32^{\circ} \mathrm{C}\end{array}$ & 0.713 & 0.816 & & & {$[25,65]$} \\
\hline & & $\begin{array}{l}\text { Average heat index of } \\
\text { June-September }\end{array}$ & 0.642 & 0.821 & & & [25] \\
\hline & & Number of tropical nights & 0.900 & 0.906 & & & $\begin{array}{c}{[2,13,24,25,64,65} \\
99,101]\end{array}$ \\
\hline & & $\begin{array}{l}\text { Number of days under a heat } \\
\text { wave }\end{array}$ & 0.872 & 0.937 & & & $\begin{array}{c}{[2,13,24,25,65,97} \\
99,101,102]\end{array}$ \\
\hline
\end{tabular}

${ }^{1}$ Most Probable Number; ${ }^{2}$ Standardized Precipitation Index; ${ }^{3}$ Effective Drought Index. 


\section{Appendix B}

Table A2. Multicriteria inventory classification of evaluation indicators considering the socio-economic sector and the outcome of the factor and reliability analysis.

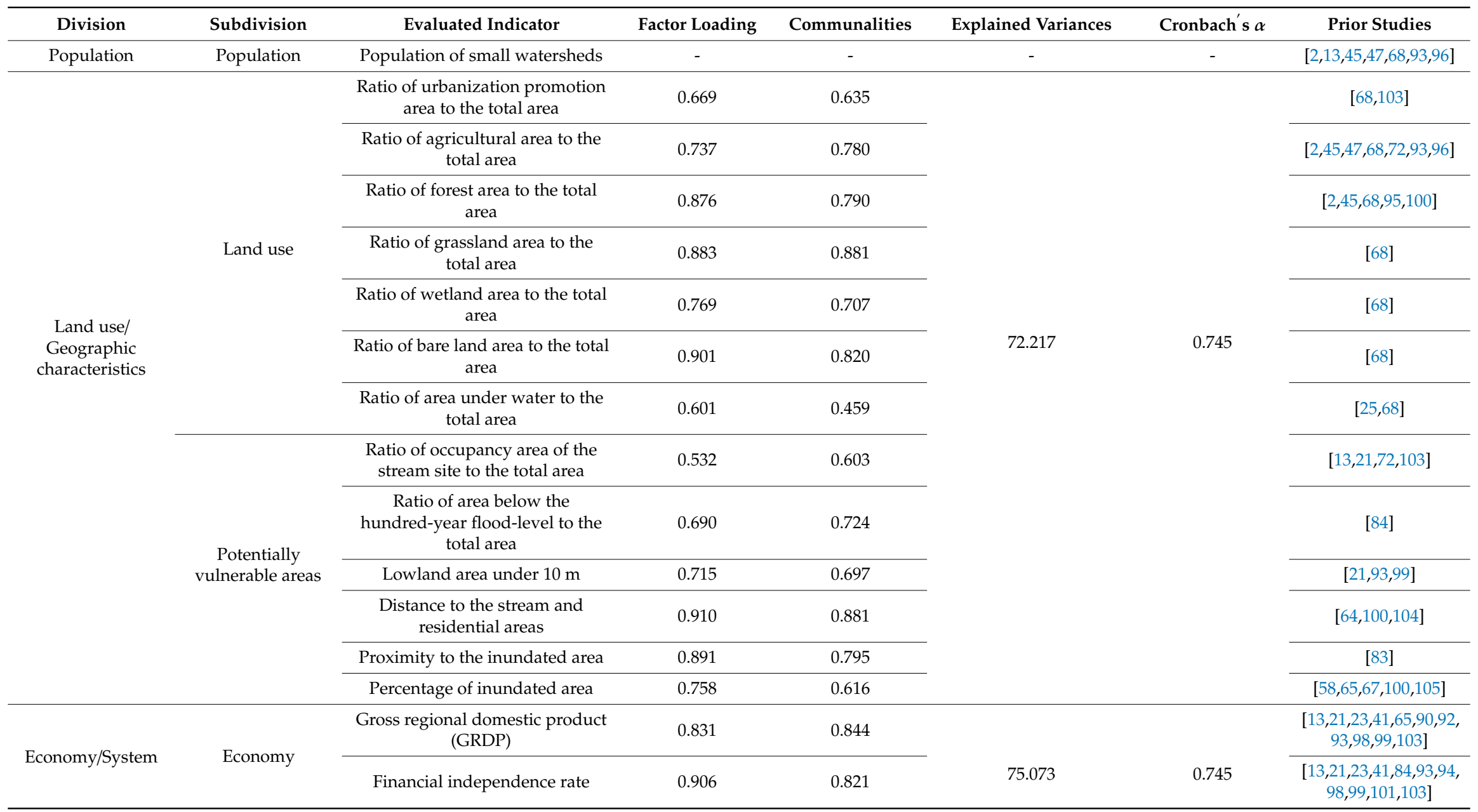


Table A2. Cont.

\begin{tabular}{|c|c|c|c|c|c|c|c|}
\hline Division & Subdivision & Evaluated Indicator & Factor Loading & Communalities & Explained Variances & Cronbach's $\alpha$ & Prior Studies \\
\hline & Policy capacity & $\begin{array}{c}\text { Environmental/disaster/safety } \\
\text { management and firefighting } \\
\text { officials }\end{array}$ & 0.728 & 0.645 & & & {$[21,59,98,103]$} \\
\hline & & Cost of stream restoration & 0.684 & 0.606 & & & [67] \\
\hline & & $\begin{array}{c}\text { Disaster management capacity of } \\
\text { local government }\end{array}$ & 0.900 & 0.837 & & & {$[84,103]$} \\
\hline \multirow{17}{*}{ Infrastructure } & Road/industry & Road density & 0.852 & 0.851 & \multirow{17}{*}{83.692} & \multirow{17}{*}{0.929} & $\begin{array}{c}{[2,13,21,25,58,65,93-} \\
95,98,103]\end{array}$ \\
\hline & \multirow{2}{*}{ Evacuation } & Number of shelters & 0.708 & 0.927 & & & [83] \\
\hline & & Information on evacuation routes & 0.769 & 0.774 & & & {$[83]$} \\
\hline & \multirow{5}{*}{ Industrial facilities } & Area of water supply facilities & 0.760 & 0.759 & & & {$[65,72]$} \\
\hline & & Area of electricity supply facilities & 0.736 & 0.834 & & & {$[65,72]$} \\
\hline & & Area of gas supply facilities & 0.893 & 0.922 & & & {$[65,72]$} \\
\hline & & Area of heat supply facilities & 0.857 & 0.894 & & & {$[65,72]$} \\
\hline & & $\begin{array}{l}\text { Area of oil storage and oil supply } \\
\text { facilities }\end{array}$ & 0.769 & 0.698 & & & {$[65,72]$} \\
\hline & \multirow{9}{*}{$\begin{array}{l}\text { Water supply } \\
\text { facilities }\end{array}$} & $\begin{array}{l}\text { Capacity of flood-control dam } \\
\text { and reservoir }\end{array}$ & 0.916 & 0.857 & & & {$[21,58,61,83,94]$} \\
\hline & & $\begin{array}{l}\text { Capacity of domestic drainage } \\
\text { facilities }\end{array}$ & 0.738 & 0.900 & & & {$[21,58]$} \\
\hline & & $\begin{array}{c}\text { Capacity of rainwater pumping } \\
\text { station }\end{array}$ & 0.832 & 0.853 & & & {$[58,94,105]$} \\
\hline & & $\begin{array}{c}\text { Capacity of storm water storage } \\
\text { tank }\end{array}$ & 0.634 & 0.935 & & & {$[94,105]$} \\
\hline & & $\begin{array}{l}\text { Whether to secure emergency } \\
\text { drainage facilities }\end{array}$ & 0.608 & 0.841 & & & [64] \\
\hline & & Sewage distribution rate & 0.632 & 0.806 & & & $\begin{array}{c}{[2,13,62,84,89,94,101} \\
103]\end{array}$ \\
\hline & & Water supply distribution rate & 0.824 & 0.804 & & & {$[62,93,95,101,103]$} \\
\hline & & Water demand per unit area & 0.719 & 0.884 & & & {$[62,95]$} \\
\hline & & Groundwater availability & 0.603 & 0.710 & & & {$[62,96,106]$} \\
\hline
\end{tabular}


Table A2. Cont.

\begin{tabular}{|c|c|c|c|c|c|c|c|}
\hline Division & Subdivision & Evaluated Indicator & Factor Loading & Communalities & Explained Variances & Cronbach's $\alpha$ & Prior Studies \\
\hline \multirow{9}{*}{$\begin{array}{l}\text { Experience/Damage } \\
\text { restoration }\end{array}$} & \multirow{3}{*}{ Extent of damage } & Property damage & 0.572 & 0.614 & \multirow{9}{*}{77.885} & \multirow{9}{*}{0.875} & {$[21,58,94,105]$} \\
\hline & & Total number of victims & 0.784 & 0.848 & & & {$[21,99,105]$} \\
\hline & & Number of casualties & 0.794 & 0.883 & & & {$[21,99,103]$} \\
\hline & \multirow{3}{*}{ Vulnerable areas } & $\begin{array}{c}\text { Ratio of flooding area to the total } \\
\text { area }\end{array}$ & 0.817 & 0.704 & & & {$[58,72]$} \\
\hline & & $\begin{array}{l}\text { Ratio of area prone to floods to } \\
\text { the total area }\end{array}$ & 0.920 & 0.855 & & & [99-101,103-105] \\
\hline & & Area habitually under drought & 0.806 & 0.667 & & & [101] \\
\hline & \multirow[t]{3}{*}{$\begin{array}{l}\text { Restoration } \\
\text { capacity }\end{array}$} & Damage recovery cost & 0.872 & 0.783 & & & [105] \\
\hline & & $\begin{array}{l}\text { Number of disaster recovery } \\
\text { projects }\end{array}$ & 0.906 & 0.837 & & & [84] \\
\hline & & $\begin{array}{l}\text { Number of psychological } \\
\text { recovery support projects for } \\
\text { disaster victims }\end{array}$ & 0.905 & 0.818 & & & [107] \\
\hline
\end{tabular}




\section{References}

1. World Meteorological Organization (WMO). The Global Climate in 2015-2019. Available online: https: //library.wmo.int/doc_num.php?explnum_id=9936 (accessed on 28 October 2020).

2. Lee, K.H.; Chung, E.G.; Kim, K.H.; Yu, J.A.; Lee, E.J. Vulnerability assessment of water quality and aquatic ecosystem to climate change in Korea using proxy variables. J. Korean Soc. Water Environ. 2012, 28, 444-452.

3. Lee, J.K.; Kim, Y.O.; Kang, N.E. Analysis of Climate Change Researches Related to Water. Clim. Chang. Res. 2012, 3, 71-88.

4. Trimmel, H.; Weihs, P.; Leidinger, D.; Formayer, H.; Kalny, G. Can riparian vegetation shade mitigate the expected rise in stream temperatures during heat waves in a pre-alpine river? Hydrol. Earth Syst. Sci. Discuss. 2018, 22, 437-461. [CrossRef]

5. Kundzewicz, Z.W.; Kanae, S.; Seneviratne, S.I.; Handmer, J.; Nicholls, N.; Peduzzi, P.; Mechler, R.; Bouwer, L.M.; Arnell, N.; Mach, K.; et al. Le risque d'inondation et les perspectives de changement climatique mondial et régional. Hydrol. Sci. J. 2014, 59, 1-28. [CrossRef]

6. Holling, C.S. Resilience and stability of ecological systems. Rev. Lit. Arts Am. 1973, 4, 1-23. [CrossRef]

7. Folke, C. Resilience: The emergence of a perspective for social-ecological systems analyses. Glob. Environ. Chang. 2006, 16, 253-267. [CrossRef]

8. Randhir, T.O. Resilience of Watershed Systems to Climate Change. J. Earth Sci. Clim. Chang. 2014, 5, e109. [CrossRef]

9. Artmann, M.; Bastian, O.; Grunewald, K. Using the concepts of green infrastructure and ecosystem services to specify leitbilder for compact and green cities-The example of the landscape plan of Dresden (Germany). Sustainability 2017, 9, 198. [CrossRef]

10. Reisinger, A.J.; Woytowitz, E.; Majcher, E.; Rosi, E.J.; Belt, K.T.; Duncan, J.M.; Kaushal, S.S.; Groffman, P.M. Changes in long-term water quality of Baltimore streams are associated with both gray and green infrastructure. Limnol. Oceanogr. 2019, 64, S60-S76. [CrossRef]

11. Keeley, M.; Koburger, A.; Dolowitz, D.P.; Medearis, D.; Nickel, D.; Shuster, W. Perspectives on the use of green infrastructure for stormwater management in cleveland and milwaukee. Environ. Manag. 2013, 51, 1093-1108. [CrossRef] [PubMed]

12. Flynn, C.D.; Davidson, C.I. Adapting the Social-Ecological System Framework for Urban Stormwater Management: The Case of Green Infrastructure Adoption. Available online: https://www.ecologyandsociety. org/vol21/iss4/art19/ (accessed on 29 October 2020).

13. Yoo, G.Y.; Kim, I.E. Development and Application of a Climate Change Vulnerability Index; Korea Environment Institute: Seoul, Korea, 2008; ISBN 9788984643215.

14. Jeon, E.Y.; Byun, B.S. A study on the development and application of community resilience evaluation indicators for Responding to climate change. Geogr. J. Korea 2017, 51, 47-58.

15. Hwang, S.A.; Hwang, S.J.; Park, S.R.; Lee, S.W. Examining the relationships between watershed urban land use and stream water quality using linear and generalized additive models. Water 2016, 8, 155. [CrossRef]

16. Kim, J.A.; Lee, S.W.; Hwang, G.S.; Hwang, S.J.; Kim, C.G.; An, K.J. Effects of streamline complexity on the relationships between urban land use and ecological communities in streams. Paddy Water Environ. 2016, 14, 299-312. [CrossRef]

17. Vugteveen, P.; Rouwette, E.; Stouten, H.; van Katwijk, M.M.; Hanssen, L. Developing social-ecological system indicators using group model building. Ocean Coast. Manag. 2015, 109, 29-39. [CrossRef]

18. Beckingham, B.; Callahan, T.; Vulava, V. Stormwater ponds in the southeastern, U.S. coastal plain: Hydrogeology, contaminant fate, and the need for a social-ecological framework. Front. Environ. Sci. 2019, 7, 1-14. [CrossRef]

19. Park, T.S.; Kim, K.M.; Yoon, Y.S.; Lee, S.B. Analysis of Flood Damage Characteristics and Development of Flood Damage Index; Korea research Institute for human settlements: Daejeon, Korea, 2005.

20. Kotzee, I.; Reyers, B. Piloting a social-ecological index for measuring flood resilience: A composite index approach. Ecol. Indic. 2016, 60, 45-53. [CrossRef]

21. Kim, Y.K.; Yoo, J.A.; Chong, E.S. Water management vulnerability assessment considering. J. Clim. Chang. Res. 2012, 3, 1-12.

22. Koh, J.K.; Kim, H.S. A study on local vulnerability assessment to climate change-The case of municipalities of Gyeonggi-Do. J. Environ. Policy Adm. 2010, 18, 79-105. 
23. Lee, B.D.; Kim, B.T.; Cho, Y.S. A study on vulnerability assessment to climate change in regional fisheries of Korea. J. Fish. Bus. Adm. 2011, 42, 57-70.

24. Koo, Y.S.; Kim, J.E.; Kim, J.S.; Lee, S.H. Study on the improvement of adaptation ability by vulnerability analysis of heat wave-The case of Busan metropolitan city. J. Korean Reg. Dev. Assoc. 2015, 27, 331-348.

25. Kim, K.; Eum, J.H. Policies for improving thermal environment using vulnerability assessment-A case study of Daegu, Korea. J. Korea Assoc. Geogr. Inf. Stud. 2018, 21, 1-23. [CrossRef]

26. Choi, E.H.; Bae, S.S.; Jee, H.K. Prioritization for water storage increase of Agricultural reservoir using FAHP method. J. Korea Water Resour. Assoc. 2013, 46, 171-182. [CrossRef]

27. Yang, X.L.; Ding, J.H.; Hou, H. Application of a triangular fuzzy AHP approach for flood risk evaluation and response measures analysis. Nat. Hazards 2013, 68, 657-674. [CrossRef]

28. Shin, J.Y.; Park, Y.J.; Kim, T.W. Evaluation of Inland Inundation Risk in Urban Area using Fuzzy AHP. J. Korea Water Resour. Assoc. 2014, 47, 789-799. [CrossRef]

29. Kabir, G.; Ahsan Akhtar Hasin, M. Comparative analysis of ahp and fuzzy ahp models for multicriteria inventory classification. Int. J. Fuzzy Log. Syst. 2011, 1, 1-16.

30. Ishizaka, A. Comparison of fuzzy logic, AHP, FAHP and hybrid fuzzy AHP for new supplier selection and its performance analysis. Int. J. Integr. Supply Manag. 2014, 9, 1-22. [CrossRef]

31. Mosadeghi, R.; Warnken, J.; Tomlinson, R.; Mirfenderesk, H. Comparison of Fuzzy-AHP and AHP in a spatial multi-criteria decision making model for urban land-use planning. Comput. Environ. Urban Syst. 2015, 49, 54-65. [CrossRef]

32. Plebankiewicz, E.; Kubek, D. Multicriteria selection of the building material supplier using AHP and fuzzy AHP. J. Constr. Eng. Manag. 2016, 142, 04015057. [CrossRef]

33. Özdağoğlu, A.; Özdağoğlu, G. Comparison of AHP and Fuzzy AHP for the multi-criteria decision making processes with linguistic evaluations. İstanbul Ticaret Üniversitesi Fen Bilim. Derg. 2007, 6, 65-85.

34. Sander, H.A.; Polasky, S. The value of views and open space: Estimates from a hedonic pricing model for Ramsey County, Minnesota, USA. Land Use Policy 2009, 26, 837-845. [CrossRef]

35. Scott Shafer, C.; Scott, D.; Baker, J.; Winemiller, K. Recreation and amenity values of Urban Stream corridors: Implications for green infrastructure. J. Urban Des. 2013, 18, 478-493. [CrossRef]

36. United States Environmental Protection Agency (USEPA). Reducing Stormwater Costs through Low Impact Development (LID) Strategies and Practices. Available online: https:/www.epa.gov/sites/production/ files/2015-10/documents/2008_01_02_nps_lid_costs07uments_reducingstormwatercosts-2.pdf (accessed on 29 October 2020).

37. Liu, Y.; Theller, L.O.; Pijanowski, B.C.; Engel, B.A. Optimal selection and placement of green infrastructure to reduce impacts of land use change and climate change on hydrology and water quality: An application to the Trail Creek Watershed, Indiana. Sci. Total Environ. 2016, 553, 149-163. [CrossRef]

38. Han, M.Y.; Kim, J.K.; Park, S.C. The effect of greening roof on the quantity and quality of rainfall runoff. J. Archit. Inst. Korea Plan. Des. 2003, 19, 279-285.

39. Mei, C.; Liu, J.; Wang, H.; Yang, Z.; Ding, X.; Shao, W. Integrated assessments of green infrastructure for flood mitigation to support robust decision-making for sponge city construction in an urbanized watershed. Sci. Total Environ. 2018, 639, 1394-1407. [CrossRef] [PubMed]

40. Lee, H.M.; You, S.J.; Park, S.; Chon, J.H. A study on categories of green infrastructure to enhance urban resilience. J. Korea Plan. Assoc. 2018, 53, 215-235. [CrossRef]

41. Park, S.M.; Lee, W.K.; Kwon, T.H.; Lee, B.D.; Son, Y.H.; Cho, Y.S. Vulnerabilitiy assessment for ocean to climate change using Spatial information based on GIS. Spat. Inf. Res. 2011, 19, 1-9.

42. McClanahan, T.R.; Donner, S.D.; Maynard, J.A.; MacNeil, M.A.; Graham, N.A.J.; Maina, J.; Baker, A.C.; Beger, M.; Campbell, S.J.; Darling, E.S.; et al. Prioritizing key resilience indicators to support coral Reef management in a Changing climate. PLoS ONE 2012, 7, 1-7. [CrossRef]

43. Davidson, J.L.; van Putten, I.E.; Leith, P.; Nursey-Bray, M.; Madin, E.M.; Holbrook, N.J. Toward Operationalizing Resilience Concepts in Australian Marine Sectors Coping with Climate Change. Available online: https: //www.ecologyandsociety.org/vol18/iss3/art4/ (accessed on 29 October 2020).

44. Moore, S.E.; Huntington, H.P. Arctic marine mammals and climate change: Impacts and resilience. Ecol. Appl. 2008, 18, S157-S165. [CrossRef]

45. Kim, S.J.; Kim, S.M.; Kim, S.M. A study on the vulnerability assessment for agricultural infrastructure using principal component analysis. J. Korean Soc. Agric. Eng. 2013, 55, 31-38. [CrossRef] 
46. Douxchamps, S.; Debevec, L.; Giordano, M.; Barron, J. Monitoring and evaluation of climate resilience for agricultural development-A review of currently available tools. World Dev. Perspect. 2017, 5, 10-23. [CrossRef]

47. Kim, M.H.; Bang, H.S.; Na, Y.E.; Kim, M.R.; Oh, Y.J.; Kang, K.K.; Cho, K.J. Vulnerability assessment of rice production by main disease and pest of rice plant to climate change. J. Korea Soc. Environ. Restor. Technol. 2013, 16, 147-157. [CrossRef]

48. Ifejika Speranza, C. Resilient Adaptation to Climate Change in African Agriculture; German Development Institute: Born, Germany, 2010; ISBN 9783889854896.

49. Byun, J.Y.; Lee, W.K.; Choi, S.H.; Oh, S.H.; Yoo, S.J.; Kwon, T.S.; Sung, J.H.; Woo, J.W. Vulnerability assessment for forest ecosystem to climate change based on spatio-temporal information. Korean J. Remote Sens. 2012, 28, 159-169. [CrossRef]

50. Lim, S.J.; Kim, H.J.; Lee, S.H. Forest vulnerability assessment of Pine and pine mushroom using GIS. J. Agric. Life Sci. 2014, 48, 1-11. [CrossRef]

51. Davoudi, S.; Shaw, K.; Haider, L.J.; Quinlan, A.E.; Peterson, G.D.; Wilkinson, C.; Fünfgeld, H.; McEvoy, D.; Porter, L. Resilience: A bridging concept or a dead end? "Reframing" resilience: Challenges for planning theory and practice interacting traps: Resilience assessment of a pasture management system in Northern Afghanistan Urban resilience: What Does it mean in planni. Plan. Theory Pract. 2012, 13, 299-333. [CrossRef]

52. Eum, J.H. Vulnerability assessment to urban thermal environment for spatial planning-A case study of Seoul, Korea. J. Korean Inst. Landsc. Archit. 2016, 44, 109-120. [CrossRef]

53. Durance, I.; Ormerod, S.J. Climate change effects on upland stream macroinvertebrates over a 25-year period. Glob. Chang. Biol. 2007, 13, 942-957. [CrossRef]

54. Bêche, L.A.; Connors, P.G.; Resh, V.H.; Merenlender, A.M. Resilience of fishes and invertebrates to prolonged drought in two California streams. Ecography 2009, 32, 778-788. [CrossRef]

55. Lawrence, J.E.; Lunde, K.B.; Mazor, R.D.; Bêche, L.A.; McElravy, E.P.; Resh, V.H. Long-term macroinvertebrate responses to climate change: Implications for biological assessment in mediterranean-climate streams. J. N. Am. Benthol. Soc. 2010, 29, 1424-1440. [CrossRef]

56. Lee, M.H.; Jung, I.W.; Bae, D.H. Korean flood vulnerability assessment on climate change. J. Korea Water Resour. Assoc. 2011, 44, 653-666. [CrossRef]

57. Muller, M. Adapting to climate change: Water management for urban resilience. Environ. Urban. 2007, 19, 99-113. [CrossRef]

58. Kim, D.E.; Jung, Y.; Park, M.J.; Yoon, J.Y.; Kim, S.D.; Choi, M.H. Vulnerability analysis of water resources considering climate change. J. Wetl. Res. 2011, 13, 25-33.

59. Park, H.S.; Kim, H.J.; Chae, Y.R.; Kim, Y.J. Assessment of water use vulnerability considering climate and socioeconomic changes in Han river watershed. J. Korean Soc. Civ. Eng. 2017, 37, 965-972.

60. Ahn, J.H.; Hong, Y.S.; Kang, H.S.; Han, D.H.; Jang, J.H.; Seo, D.I.; Park, Y.H. Water Quality Management Strategy in the Context of Climate Change; Korea Enviornment Institute: Sejong, Korea, 2010; ISBN 9788984645257.

61. Bae, D.H.; Lee, M.H. Flood vulnerability assessment and case analysis due to climate change. Korea Res. Inst. Hum. Settl. 2010, 20-31.

62. Chung, J.W.; Lee, W.K.; Cui, G.S.; Lee, S.C.; Choi, S.H.; Choi, H.A. Application study of vulnerability assessment models for water resources to climate change by spatial and watershed scales. J. Clim. Chang. Res. 2010, 1, 21-30.

63. Lee, B.W.; Chung, D.H.; Kim, B.C. Relative importance evaluation of advertising agency selection sing AHP. Korean J. Adevert. Public Relat. 2011, 13, 7-30.

64. Seoul National University (SNU). MOE Research on Climate Change Vulnerability Survey/Evaluation Measures Such as Non-Point Pollution Reduction Facilities; SNU: Seoul, Korea, 2014.

65. Han, W.S.; Sim, O.B.; Lee, B.J.; You, J.H. The proposal of evaluation method for local government infrastructure vulnerability relating to climate change driven flood. J. Clim. Chang. Res. 2012, 3, $25-37$.

66. Myung, S.J.; Kim, J.Y.; Shin, S.H.; An, B.O. Assessing Vulnerability to Climate Change of the Physical Infrastructure and Developing Adaptation Measures in Korea II; Korea Environment Institute: Seoul, Korea, 2010; ISBN 9788984645196. 
67. Ryu, J.N.; Hwang, S.I.; Kim, H.J.; Lee, B.K.; Lee, Y.K.; Jung, A.Y. Sustainability Assessment of Water Infrastructure and Services. Available online: https:/library.kei.re.kr:444/dmme/img/001/014/007/\%ec\%82\% ac\%ec\%97\%85_2018_03_\%eb\%a5\%98\%ec\%9e\%ac\%eb\%82\%98_\%ed\%99\%a9\%ec\%83\%81\%ec\%9d\%bc.pdf (accessed on 29 October 2020).

68. Ministry of Environment. Guide to Diagmosis of Health Deterioration in River Aquatic Ecosystem; MOE: Sejong, Korea, 2019.

69. Saaty, T.L. A scaling method for priorities in hierarchical structures. J. Math. Psychol. 1977, 15, $234-281$. [CrossRef]

70. Srdjevic, B.; Medeiros, Y.D.P. Fuzzy AHP assessment of water management plans. Water Resour. Manag. 2008, 22, 877-894. [CrossRef]

71. Chae, B.G.; Cho, Y.C.; Song, Y.S.; Seo, Y.S. Development of an evaluation chart for landslide susecptivility using the AHP analysis method. J. Eng. Geol. 2009, 19, 99-108.

72. Koh, J.K.; Kim, H.S. A study on Vulnerability Assessment to Climate Change in Gyeonggi-Do; Gyeonggi Research Institute: Gyeonggi, Korea, 2009.

73. Song, K.W.; Lee, Y. Re-scaling for improvement the consistency of the AHP method. Soical Sci. Res. Rev. 2007, 29, 271-288.

74. Cho, S.K.; Lee, J.S. Development of the attributes and their weights for evaluation of amenity of seoul by applying fuzzy-AHP. Seoul Stud. 2006, 7, 1-16.

75. Lee, S. Determination of priority weights under multiattribute decision-making situations: Ahp versus fuzzy ahp. J. Constr. Eng. Manag. 2015, 141, 1-9. [CrossRef]

76. Kutlu, A.C.; Ekmekçioğlu, M. Fuzzy failure modes and effects analysis by using fuzzy TOPSIS-based fuzzy AHP. Expert Syst. Appl. 2012, 39, 61-67. [CrossRef]

77. Van Laarhoven, J.M.P.; Pedrtycz, W. A fuzzy extension of Saaty's priority theory. Fuzzy Sets Syst. 1983, 11, 229-241. [CrossRef]

78. Mo, S.W.; Kim, C.B. A Relative Importance Evaulation of the industrial sector according to the FTA using AHP and fuzzy AHP. J. Ind. Econ. Bus. 2012, 25, 1827-1842.

79. Dağdeviren, M.; Yüksel, I. Developing a fuzzy analytic hierarchy process (AHP) model for behavior-based safety management. Inf. Sci. 2008, 178, 1717-1733. [CrossRef]

80. Chung, D.H.; Yang, H.C. Reliability and validity assessment in 3D video measurement. J. Broadcast Eng. 2012, 17, 49-59. [CrossRef]

81. Young, A.; Sean, P. A beginner's guide to factor analysis: Focusing on exploratory factory analysis. Tutor. Quant. Methods Psychol. 2013, 9, 79-94. [CrossRef]

82. Taherdoost, H. Sampling methods in research methodology; How to choose a sampling technique for research. Int. J. Acad. Res. Manag. 2016, 5, 18-27. [CrossRef]

83. Balica, S.F.; Douben, N.; Wright, N.G. Flood vulnerability indices at varying spatial scales. Water Sci. Technol. 2009, 60, 2571-2580. [CrossRef]

84. Park, G.J.; Kim, H.S.; Park, M.J.; Kin, S.D.; Choi, M.H.; Yoon, J.Y. Assessment of flood vulnerability considering climate change using entropy method. J. Korean Soc. Hazard Mitig 2011, 1, 263-264.

85. Hwang, Y.J. Application of geographic database for prediction of flood vulnerable area. J. Korean Assoc. Reg. Geogr. 2006, 12, 172-178.

86. Jun, H.D.; Kim, S.J. Analysis of future hydrological cycle considering the impact of climate change and hydraulic structures in Geum River Basin. J. Korean Soc. Hazard Mitig. 2014, 14, 299-309. [CrossRef]

87. Hahm, C.H.; Kim, G.H. A study of ecological flow assesment for environmental development in natural river. J. Korean Soc. Geospat. Inf. Sci. 2010, 18, 47-53.

88. Ahn, S.R.; Lee, Y.J.; Park, G.A.; Kim, S.J. Analysis of fucture land use and climate change impact on stream discharge. J. Korean Soc. Civ. Eng. B 2008, 28, 215-224.

89. Kim, E.S.; Yoon, K.Y.; Lee, S.H. Lake vulnerability assessment. J. Korea Acad. Coop. Soc. 2014, 15, 6877-6883. [CrossRef]

90. Lee, J.W.; Chun, S.H.; Kim, K.H.; Kim, C.W. Flow analysis based on the recovery of lateral connectivity in the River. J. Wetl. Res. 2014, 16, 213-220. [CrossRef]

91. Hare, J.A.; Morrison, W.E.; Nelson, M.W.; Stachura, M.M.; Teeters, E.J.; Griffis, R.B.; Alexander, M.A.; Scott, J.D.; Alade, L.; Bell, R.J.; et al. A vulnerability assessment of fish and invertebrates to climate change on the Northeast, U.S. continental shelf. PLOS ONE 2016, 11, 1-30. [CrossRef] 
92. Jo, Y.T.; Kim, H.C.; Kim, G.H.; Nam, K.H.; Kim, H.T. A Study on vulnerability assessment of water quality caused by drought in daegu metropolitan city. J. Korea Soc. Water Environ. 2018, 34, 223-224.

93. Kang, J.Y.; Oh, K.S. Establishing flood vulnerability assessment indicies for climate chagne adaptation and its application: The case of the Seoul metropolitan area. J. Korean Urban Manag. Assoc. 2014, 27, 43-67.

94. Jung, Y.; Choi, M.H. Survey-based approach for hydrological vulnerability indicators due to climate change: Case study of small-scale rivers. J. Am. Water Resour. Assoc. 2012, 48, 256-265. [CrossRef]

95. Oh, S.H.; Lee, W.K.; Byun, J.Y.; Park, S.M.; Kwak, H.B.; Cui, G.S.; Kim, M.I.; Jung, R.S.; Nam, K.J.; Shin, D.H. A study on vulnerability assessment and prioritizing sectors to support adaptation strategy to climate change-Case study of Gangwon province. J. Clim. Chang. Res. 2012, 3, 245-257.

96. Shin, H.J.; Kwon, H.J.; Lee, J.Y.; Lee, J.H.; Park, C.G. Vulnerability evaluation for water supply of irrigation facilities: Focusing on Dangjin-si, Yesan-gun, Cheongyang-gun, South Korea. J. Korean Soc. Agric. Eng. 2018, 60, 33-42. [CrossRef]

97. Kim, C.C.; Kim, T.G. Evaluation on climate change vulnerability of Korea National Parks. Korean, J. Ecol. Environ. 2016, 49, 42-50. [CrossRef]

98. Lee, S.H.; Kang, J.E.; Bae, H.J.; Yoon, D.K. Vulnerability assessment of the air pollution using entropy weights: Focused on ozone. J. Korean Assoc. Reg. Geogr. 2015, 21, 751-763.

99. Lee, J.H. A study on linkage methodology between climate change vulnerability assessment and adapation policy. Korea Resour. Econ. Assoc. Conf. 2016, 235-266.

100. Kang, J.E.; Lee, M.J. Assessment of flood vulnerability to climate change using fuzzy model and GIS in Seoul. J. Korean Assoc. Geogr. Inf. Stud. 2012, 15, 119-136. [CrossRef]

101. Kim, S.M.; Kim, N.E. A study on vulnerability assessment to climate change-Focused on 22 municipalities of JeollaNamDo. J. Korea Assoc. Gov. 2012, 19, 99-123. [CrossRef]

102. Yoo, S.J.; Lee, W.K.; Oh, S.H.; Byun, J.Y. Vulnerability assessment for public health to climate change using Spatio-temporal information based on GIS. J. Korea Spat. Inf. Soc. 2012, 20, 13-24. [CrossRef]

103. Myung, S.J. Cliamte change vulnerability assessment using spatial analysis. Water Futur. 2011, 44, 57-62. [CrossRef]

104. Adelekan, I.O. Vulnerability assessment of an urban flood in Nigeria: Abeokuta flood 2007. Nat. Hazards 2011, 56, 215-231. [CrossRef]

105. Hwang, H.S.; Byun, B.S. Building vulnerability index on climate change: Focused on Seoul metropolitan city. J. Environ. Policy Adm. 2011, 19, 93-119.

106. Sullivan, C.; Meigh, J. Targeting attention on local vulnerabilities using an integrated index approach: The example of the climate vulnerability index. Water Sci. Technol. 2005, 51, 69-78. [CrossRef] [PubMed]

107. Hyun, J.H.; Kim, H.S.; Ahn, Y.J. Examination on Koreas disaster psychological support services based on 912 Gyeongju earthquake experience. J. Community Welf. 2018, 65, 169-201. [CrossRef]

Publisher's Note: MDPI stays neutral with regard to jurisdictional claims in published maps and institutional affiliations.

(C) 2020 by the authors. Licensee MDPI, Basel, Switzerland. This article is an open access article distributed under the terms and conditions of the Creative Commons Attribution (CC BY) license (http://creativecommons.org/licenses/by/4.0/). 